\title{
ENHANCING NETIZEN AS A DIGITAL MARKETING ACTIVITY TOWARD STRATEGIC BRANDING: A CASE STUDY OF “XYZ” BRAND
}

\author{
Nila Krisnawati Hidayat; Rudy Tobing \\ Swiss German University \\ EduTown BSDCity, Tangerang 15339, Indonesia \\ nila.hidayat@sgu.ac.id
}

\begin{abstract}
This study is focused on the role of netizen in digital marketing activities to attempt the development of strategic brand of "XYZ". The purpose of this study to identify whether netizen as users have recognize the "XYZ” brand as a product of internet mobile, through four variables of brand performances: delivery message, creative advertisement, product understanding, and brand association. It is also to measure users' level of awareness to the website of "murah itu XYZ". The research methodology applied in this study is descriptive quantitative study using Likert scale. The result shows that the highest level of brand performance is not only from delivery message, but it also indicates that netizen have recognized the "XYZ" as internet mobile under the activity of digital marketing. In addition, users are not aware yet to the website of "murah itu XYZ". The content of the mobile advertising should be increased in the near future.
\end{abstract}

Keywords: netizen, digital marketing, strategic branding

\begin{abstract}
ABSTRAK
Penelitian ini difokuskan pada peran pengguna internet dalam kegiatan pemasaran digital untuk mengembangkan merek strategis "XYZ". Tujuan penelitian ini yaitu untuk mengidentifikasi apakah netizen sebagai pengguna harus mengetahui merek "XYZ" sebagai produk internet mobile, melalui empat variabel kinerja merek: pengiriman pesan, iklan kreatif, pemahaman produk, dan asosiasi merek. Hal ini juga untuk mengukur tingkat kesadaran pengguna kepada website "murah itu XYZ". Penelitian ini menggunakan metodologi kuantitatif deskriptif dengan skala Likert. Hasil penelitian menunjukkan bahwa tingkat tertinggi kinerja merek tidak hanya dari pengiriman pesan, tetapi juga menunjukkan bahwa pengguna internet telah mengakui "XYZ" sebagai internet mobile di bawah kegiatan pemasaran digital. Selain itu, pengguna belum paham betul akan situs "murah ITU XYZ". Dengan demikian, konten iklan mobile harus ditingkatkan dalam waktu dekat.
\end{abstract}

Kata kunci: pengguna internet, pemasaran digital, merek strategis 


\section{INTRODUCTION}

The prospect of Indonesian telecommunications sector in 2012 is predicted to be stable. In fact, intense competition in the business will erode corporate profit margins. Five of the largest telecommunication companies in Indonesia, namely PT Telekomunikasi Indonesia Tbk (TLKM), PT Telkomsel Mobile, PT Indosat Tbk (ISAT), PT XL Axiata Tbk (EXCL) and PT Bakrie Telecom Tbk (BTEL), will still control 90 percents of the market.

Transportation and communication sector contributes very significant to the growth of Indonesian GDP (Faisal Basri, 2010). These sectors are rapidly growing near to $80 \%$ from the total numbers of Indonesian citizen which is 240 million people. Potential unfair business competition may be happened among telecommunications operators in Indonesia because competition among the 11 operators. However, the Indonesian Telecommunications Regulatory Body (BRTI) implemented a close monitoring to avoid monopoly or cartel tariff practices, for example, operators lowered the tariff too low to attract new customers.

Align with the decreasing number of telephone and SMS use, operators began pinned their hope on the Internet data packets. While these data packets Internet is a source of the new most profitable revenue, having succeeded in the market-bypass applications by Apple and Google as the owner of the largest smart phone platform.

The biggest income contribution is estimated derived from conversations (voice calls), which up to now still dominates the consumption in Indonesia despite the introduction of mobile data such as SMS and GPRS for about 25-30 percent of its users, as well as various value added services such as content downloads and ring back tone. GPRS is General Packet Radio Services which is one of packet oriented mobile data service available to users of the $2 \mathrm{G}$ cellular communication systems for global system mobile communications (GSM), as well as in the $3 \mathrm{G}$ systems. A GPRS connection is established by reference to its access point name (APN). The APN defines the services such as wireless application protocol (WAP) access, short message service (SMS), multimedia messaging service (MMS), and internet communication services such as email and world wide web access. This data will conclude if the use of GRPS will be categorized as the use of internet access and the growth of people who use GPRS categorized the growth of netizen.

The number of netizens are for extending social groups, such as giving and receiving viewpoints, furnishing information, fostering the Internet as an intellectual and a social resource, and making choices for the self-assembled communities. The use of netizen as intellectual resource can be translated as an activity in formal ways regarding to the product such as sales and marketing process, which is called as digital marketing. The term netizen is derived from the term citizen, referring to a citizen of the Internet, or someone who uses networked resources. In the Internet-dominated world, information that can be accessed freely and is flowing through a multi-directional network can initiate issues. Considering that the Internet is used by a variety of people, it should not be surprising that the spread of information in the Internet often causes panic attacks.

\section{The Concept of Brand}

The definition of "Brand" based on Alexander Chernev (2007) is the marketing tool created with purpose of differentiating a company's offering from the competition and creating value for customer, the company, and its collaborators.

On Figure 1, brand interaction model is branding activities which primarily has an interest in brand strategy planning in the future. Brand model is used as a guide in designing, implementing, and 
evaluating the branding activities, including marketing communications. Research about the brand needs to begin with modeling of the elements of brand equity to be measured (Ike Janita Dewi , 2009).

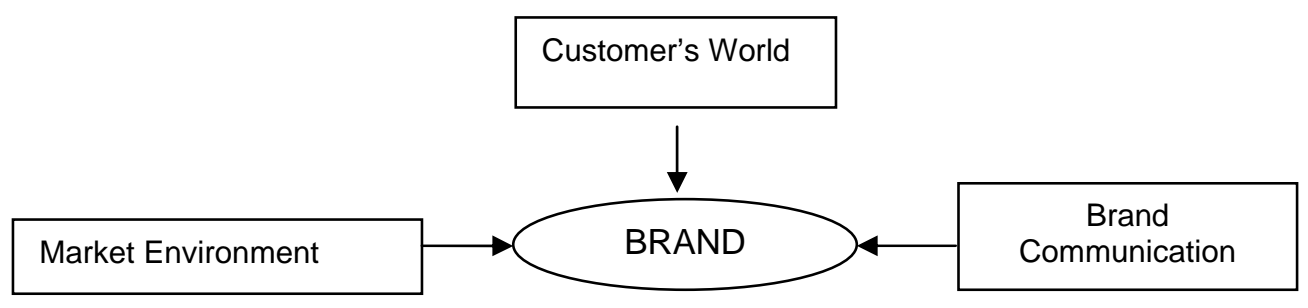

Figure 1. Brand interaction model (chandler and owen $(2002 ; 50)$.

The structures to design the brand strategy by Kevin Lane Keller (2003; 560) are: (1) identify the level of brand hierarchy; (2) desire awareness and image at each hierarchy; (3) combining brand element; (4) link it with multiple products; (5) adjust to marketing program and campaign (corporate image campaign and brand line campaign).

There are several elements of brand such as brand names, URLs, logos, character, slogan, jingles, and packaging. URLs is a uniform resouces locator which has a specify location of page on web and is also commonly reffered to domain names. In recent years, as companies clamored for space on Web, the number of registered URLs has increased dramatically (Kevin Lane Keller, 2008).

\section{Brand Environment and Communication}

A brand operates in an environment which consists of the elements of strategic planning cycle, market structure, cultural factor, customer motivation, and media attention altogether. Brand environment is the internal analysis which is essential for gaining an understanding of how global and local brands can shape the brand expression (Kogan, 2007). The issue will be business strategy, corporate culture, organizational structure, the brand's significance to the organization and relationship between global and local brand management teams all play a role in shaping the brand expression. The external analysis findings provide new input for the internal analysis. The analysis of the brand perception, in particular provides starting point for further strategic planning

David A. Aaker (2001) states that there are four factors influencing the brand equity, such as brand awareness, brand association, brand loyalty, and precieved quality. Brand equity is a set of assets and liabilities linked to a brand's name and symbol that add to or subtract from the value provided by product or service to a firm and/or that firm's customers. These elements should be actively managed. It should be recognized that their creation or maintenance requires an investment. The people and the system need to be in place so that programs that will damage them can be identified and resisted.

Brand Awareness can be a key strategic asset as well as a sustainable competitive difference. It provides the brand with sense of familiarity. Brand awareness also can be a signal of presence, commitment, and substance. Brand association is anything that is directly or indirectly linked the customer memory to a brand. The product attributes and customer benefits are the association that have obvious relevance because they provide reasons to buy and thus a basis for brand loyalty. Brand loyalty is a prime enduring asset to be installed to the customer by having the programs to generate brand loyalty itself. The competitors may duplicate a product or service, but they still face the task of 
making customer switch the brand. Brand loyalty can be based on simple habit, preference, or switching cost. The way to build a brand can be done by disseminating better, more insigthful knowledge as well as delivering better, bigger and more sophisticated idea in business (Blair et al., 2003).

Success criterias of a brand are: covers "international" scope (not merely national or regional); adds more value to the experience; based on a strong product foundation, built from an important universal human truth which becomes a binding agent for shared understanding of the brand; achieves multiple connection at various points of contact; manages a consistent style; demostrates a coherence in its marketing association, has a postive and optimistic tone, raises the spirits of its customer, be consistent across borders in the way it delivers the brand experience, takes a leadership position through its action in the marketplace and community, allows people to project something of themselves onto the brand.

\section{Social Network Communities}

The social network service, broadly conceptualized, refers to the ways in which information and communication technologies are use to leverage, articulate, and extend social networks. The growth of social network service has garnered much attention from media and from researchers. Currently, the most popular type of social network service is web-based and focused primarily on socializing activities. According to the reports by the Pew Internet \& Life project, $93 \%$ of teens use the internet and more that half (55\%) of all youth use online social networking sites. Blogs, which may be compared to online diaries, allow teens to express themselves in an environment free from parents, to explore their own identities, to form virtual relationship.

Considering the mobile phone as such a relevant technology due to its basic fuctionality as a device is one that emphasizes social connection. Mobile devices are social devices which mediate social relationship, social networks and manage the circulation of culture that sustains such network. The social network service for mobile is an application that allow users to share their location and find others in their immidiate or extended social network and broadcast messages.

\section{METHOD}

The purpose of this research is to find out any strong relationship between the emergence of netizen and strategic branding development. Therefore, the enhancement of Netizen can be a benchmark for them to create marketing activities in an attempt to develop XYZ's brand. The other reason is to identify the familiarity of blog "Murah itu XYZ" as a media communication within the users and company. The research approach applied in this thesis is a qualitative and inductive descriptive. It is implemented by gathering data from virtual questionaire as well as interviews.

The population used for this research are the user of "XYZ" brand in Indonesia. The number of population is 26 million people and the sample taken are 200 respondences. The profile of netizens which become the sample of our respondents consists of $72,36 \%$ is female and $27,64 \%$ is male. The range of ages are: 19-23years old (41\%), 24-35 years old (38\%), >35 years old (21\%). From occupation level; University students (14\%), Employee public sectors (6\%), Secondary School (16\%), High school (37\%), University Graduate. And based on income per month, 17\% have less than Rp.1 million income, 38\% have Rp.1-3 million, and 45\% have income more than Rp 3 million. 


\section{RESULTS AND DISCUSSION}

\section{The Growth of Netizen as a part of Digital Marketing Activities}

The netizen spent a large amount of their time online, utilizing the internet to engage various activities and views the internet as a source of information and for social entertainment purposes.

Since 2006, netizen population in Indonesia have increased tenfold from $1.0 \%$ to $10.5 \%$ in 2008 (Table 1). Most of netizens are early adopters of technology, urban citizen and people who are 45 years old or younger. This trend is used by marketers as an effective strategy to approach the youth subculture including media excitement, affinity engagement and role play empowerment. Starting from 2007, "XYZ" brand is focused more on internet services for its users. It indicates that "XYZ" users are the netizens. The growth of netizens are very important for "XYZ" since the target markets are youth who are often communicate virtually.

Table 1Netizen Population Trend

\begin{tabular}{lllll}
\hline Year & Users & Population & \% Growth & GDP \\
\hline 2006 & 2.000 .000 & 205.264 .595 & $1.0 \%$ & USD 570 \\
2007 & 20.000 .000 & 224.481 .729 & $8.3 \%$ & USD 1.230 \\
2008 & 25.000 .000 & 232.512 .655 & $10.5 \%$ & USD 1.925 \\
\hline \multicolumn{4}{r}{ Source: Marketing in Indonesia, 2010 }
\end{tabular}

\section{Strategic Branding Analysis of “XYZ” through Internet Media}

"XYZ" is one of telephone provider from Indosat established since 10 years ago as a trendsetter of multimedia mobile in Indonesia. "XYZ" is one of the products from indosat with the domain section of communication products such as data and voice products. The Company operates 16,353 base tranceiver stations (BTS) at 31 December 2009, including $2 \mathrm{G}$ and 3G BTSs or added 2,691 BTSs compared to the same period of last year (Indosat.Com).

The demographic segment of "XYZ" is around 14 until 34 years old of customers, with social economic condition B-D, and other criteria such as, students, young house duites, and blue collar workers which categorized as youth. The brand identity of "XYZ" or the core demograpy is around 18-22 years old people, with social economic C-D.

"XYZ" puts their brand to the position statement of cheap, fun, and excitement. The tactical statement of "XYZ" are long talk, no interuption, cheap, SMS, innovative data, and community benefit. At the end, "XYZ" claims their personality as young, fun, and innovative.

Around year 2008, "XYZ" look into the market of internet or Netizen who most of them are youth and up to date with technology development (Mac Jadalhack, 2009). On 2009, "XYZ" started to do an online campaign by introducing several packages of internet mobile and telephone service. The packages are: campaign online culture, introducing internet voucher, blackberry prepaid voucher, partnership with online community such as Mig33, Facebook, and Opera, bundling with handset called "Hape On Line and Hape Groovy". 
Packet data plays an important role on the increasing of XYZ's revenue which is generated from SMS and GRPS data. Based on the interview with "XYZ" Brand Manager, the GPRS data derives the biggest part on data revenue equal to $37 \%$ (Tabel 2). In other words, "XYZ" use the development of internet as a media to buzz their revenue.

Table 2The Growth of Internet Data Usage of "XYZ"

\begin{tabular}{ll}
\hline \multicolumn{1}{c}{ Result } & Growth \\
\hline Revenue Total & $7 \%$ \\
Revenue SMS & $6 \%$ \\
Revenue Data & $46 \%$ \\
Hit SMS & $11 \%$ \\
Traffic GPRS (data) & $37 \%$ \\
Users GPRS & $19 \%$ \\
\% GPRS users from 22\% & to be $37 \%$ \\
Blackberry on Demand & $49 \%$ \\
Sales of HaPe Online \& Groovy & 300.000 units \\
\hline
\end{tabular}

XYZ shows its development through many achievements obtained from the market. Many of its awards won by Indosat are around the area of the internet products and service that they provided, mostly after Indosat leads not only the voice products but also data products. The awards are; The Most Potential Brand by Swa Magazine \& MARS (July 2002), Brand with Fantastic Performance by Tabloid Marketing (August 2002), The Best Data Services 2009, and other else. Thus, the increasing of the revenue and awards of XYZ received in 2009 are positive outcome of the branding strategy that they made through various internet data received by the program in Indonesian society.

\section{Analysis to “XYZ” Brand Performance}

The result shows that the most important factor for respondents in communicating the mobile internet products and services are from the message that they got from the Delivery Message $(3.19 \leq \mu$ $\leq 3.54)$. According to the data gathered, "XYZ"company uses "endorser" to deliver the message of efficiency in using their internet access. They do so because the message is very important to convey to users so they understand the "XYZ" products and internet services provided clearly. It can help the company build their brands to be acknowledged better in the community. Considering the target market is the youth, "XYZ" conveys the message through the advertisement more effectively with fun tagline and song.

It means when respondents think about the good communication of "XYZ" product, they will see the message delivery by advertisment at the first. The next important factor according to the respondents is creative advertisement $(3.26 \leq \mu \leq 3.54)$. The way to presence the advertisement is a second important for the respondents in communicating the product and services of internet mobile. A creative advertisement is an advertisement that can be shown through songs, logo, unique taglines, dan campaign through social websites. Through the quistionaires, respondents agree if "XYZ" has delivered creative advertisements through social website and unique tagline.

Furthermore, the respondents agree if the message from the advertisement can be grasped by the receivers and it plays on the third position $3.28 \leq \mu \leq 3.52$. The receivers agree if the advertisment of "XYZ" has delivered a message that can be understand in public. The interval for brand association is $3.34 \leq \mu \leq 3.37$. The brand association can be determined from how famous "XYZ" brand in providing good quality of products and services. The respondents agree if XYZ is known as an 
internet provider with many attractive features and high speed services. In addition, they agree if XYZ has discovered more about customer's behavior through several programs.

To determine whether people recognise the internet mobile products from "XYZ" is being well distributed by good communication, T-test statistic is used. It is used for the reason that the emergence of Netizen is used by "XYZ" as a media to create brand startegy so that the internet mobile products become a benchmark of brand "XYZ". A number of qualified samplesis taken to form t-test statistic. The result represents the opinion of 200 respondents. It is necessary to take T-test statistic to conform that the result of the respondents are qualified.

Hypothesis test:

$\mathrm{H}_{0}=$ Netizen haven't recognised "XYZ" as a product of internet mobile. $(\mu \leq 3)$

$\mathrm{H}_{1}=$ Netizen have recognised "XYZ" as a product of internet mobile. $(\mu>3)$

Based on the null hypothesis, this research is one-tail test. It is used since the population of standard deviation is unknown and it is assumed that the population is normally distributed and the number of samples are qualified to form t-test.

In conclusion, netizen in Jakarta agree if they have recognised "XYZ" as a product of internet mobile. It indicates that "XYZ" uses the emergence of Netizen and internet product as their strategy to build their brand.

\section{The Analysis of awareness "XYZ" users to the blog of "Murah Itu XYZ"}

Based on the interview with "XYZ"s brand manager From 2007 until now, "XYZ" focuses more on online culture program through digital socialization such as, Facebook, Twitter, and website "Murah itu XYZ". The "XYZ" users are facilitated with the blog made by the company for its users to communicate each other. The blog is called "Murah itu XYZ". There are many activities can be done through this blog such as, game, information sharing about celebrity, "XYZ" promotion programs, photo upload, and other IM activities to many school. Since this blog can only be used by "XYZ" users, this research would like to analyze the awareness of "XYZ" users in Jakarta to this facility. There are four factors of awareness, such as familiarity of the product, presence of the product, commitment to the product, and substance of the product. An analysis is done based on the quistionaire with six questions about awareness of "XYZ" users to the blog "Murah itu XYZ".

From 200 quistionnaires that have been distributed, 72 people (36\%) use "XYZ" as their handphone provider. The factors about awareness are assessed with confidence interval of "XYZ" users to the website "Murah itu XYZ". Poin 1 means strongly not agree and point 5 means strongly agree.

From the source taken, some users are categorized not so familiar with the blog "Murah itu XYZ". However, the other part of users are familiar with the existence of the blog $(2.72 \leq \mu \leq 3.34)$. The blog "Murah itu XYZ" also does well presented since the result gathered is $(2.19 \leq \mu \leq 2.77)$. Many users of "XYZ" did not know if there is a blog facilitated for "XYZ" users called blog "Murah itu XYZ" that can provides benefits for them to communicate each other. If so, they will be interested in joining as a member of that blog. That is why the result of commitment to blog "Murah itu XYZ" categorized as high $(3.26 \leq \mu \leq 3.87)$. Since many users do not know the presence of blog, they did not know how to operate the blog and do not know the features inside. The substance of the blog is from $2.50 \leq \mu \leq 2.99$. This is a low point that shows us if the users of "XYZ" did not agree of the substance of blog "Murah itu XYZ". The respondent from "XYZ" users agree if they have ever heard abouth the blog "Murah itu XYZ", but they do not know if it is a facility provided by "XYZ" for its customers. 
That is why they do not know the substance of blog "Murah itu XYZ"; such as the features, how to use the blog, and so on.

Hypothesis test:

$\mathrm{H}_{0}=$ respondents are not aware to the blog "Murah itu "XYZ"'. $(\mu \leq 3)$

$\mathrm{H}_{1}=$ respondents are aware to the blog "Murah itu "XYZ"'” $(\mu>3)$

Based on the null hypothesis, this research is one-tail test. It is used since the population of standard deviation is unknown and it is assumed that the population is normally distributed and the number of samples qualified to form t-test.

\section{CONCLUSION}

In conclusion, many users of "XYZ" are not aware to the blog "Murah itu XYZ" as their facility to communicate each other virtually. Some users of "XYZ" have ever heard about blog "Murah itu XYZ" but they do not know in detail the features and services given. In addition, facing the tough competition in communication business, it is a must for "XYZ" to always keep up with new stategy and innovative products and services. Therefore, any active effort to connect and communicate to netizen will be necessary through media so that they are familiar to interact with.

\section{REFERENCES}

Aaker, David. A. (2004). Brand Portfolio Strategy. New York: Simon \& Schuster.

Blair, M., Armstrong, R., Murphy, M. 2003, The 360 Degree Brand in Asia. New Jersey: John Willey \& Sons.

Chernev, Alexander. (2007). Strategic Marketing Analysis. London: Brightstar Media.

Dewi, Ike Janita. (2009). Creating and Sustaining Brand Equity. Yogyakarta: Amara Books.

Jadalhack, Mac. Leaders in Mobile Internet. Retrieved 30 September 2009 from http://www.pocketberry.com/2009/09/30/blackberry-beats-the-iphone-in-indonesia/.

Keller, Kevin Lane. (2003). Strategic Brand Management.

Kogan, Konstantin. (2007). Supply Chain Management. Springscience.

Swa Magazine and MARS. (2002). The Most Potential Brand. Jakarta: Swa Magazine.

Tabloid Marketing. (August, 2002). Brand with Fantastic Performance. Jakarta: Tabloid Marketing 